\title{
Potential distribution of Batrachochytrium dendrobatidis in Argentina: implications in amphibian conservation
}

\author{
R. Ghirardi • M. G. Perotti • M. M. Steciow • \\ M. L. Arellano - G. S. Natale
}

Received: 19 August 2009/Accepted: 12 April 2010/Published online: 2 May 2010

(C) Springer Science+Business Media B.V. 2010

\begin{abstract}
Within the last two decades Batrachochytrium dendrobatidis (B.d.), the causative agent of chytridiomycosis, seems to have become a pandemic parasite, and is proposed as one of the more important causes of amphibian declines worldwide. In Argentina,
\end{abstract}

Guest editors: T. Sime-Ngando \& N. Niquil / Disregarded Microbial Diversity and Ecological Potentials in Aquatic Systems

R. Ghirardi $(\bowtie) \cdot$ M. M. Steciow · M. L. Arellano Instituto de Botánica Spegazzini, Facultad de Ciencias Naturales y Museo (UNLP), Calle 53 No 477, 1900 La

Plata, Buenos Aires, Argentina

e-mail: romighirardi@yahoo.com.ar

R. Ghirardi

Instituto Nacional de Limnología (INALI-UNLCONICET), Ciudad Universitaria, Paraje El Pozo, 3000 Santa Fe, Santa Fe, Argentina

M. G. Perotti

Laboratorio de Fotobiología, INIBIOMA

(UNCOMA-CONICET), Quintral 1250, 8400,

San Carlos de Bariloche, Río Negro, Argentina

M. M. Steciow - M. L. Arellano

Facultad de Ciencias Naturales y Museo

(FCNyM-UNLP), Av. 60 y 122, 1900, La Plata,

Buenos Aires, Argentina

\section{G. S. Natale}

Departamento de Química, Facultad de Ciencias Exactas (FCE-UNLP), Centro de Investigaciones y Medio Ambiente (CIMA), Calle 115 esquina 47, 1900 La Plata, Buenos Aires, Argentina the first report was in 2002 in Leptodactylus ocellatus. Since then, the fungus has expanded through different environments and species. In this study, we predict B.d. distribution in Argentina applying niche modelling based on reports of infected amphibians and environmental variables. The distribution hypothesis showed regions with highest suitability for B.d. including habitat types with (1) the most diverse amphibian fauna in Argentina such as the Paraná River Basin, (2) endangered species, such as north Patagonia and northwest Andean highlands, and (3) wide range of optimum precipitation and temperatures allowing development of B.d.

Keywords Chytridiomycosis · Ecological niche · Amphibian · Argentina

The chytrid fungus Batrachochytrium dendrobatidis (B.d) (Longcore et al., 1999) is the causative agent of the amphibians emerging infectious disease chytridiomycosis and is distributed worldwide. The earliest infection was identified in 1938 in a Xenopus laevis specimen from South Africa (Weldon et al., 2004) and since then $B . d$. has been recorded worldwide in a broad range of habitats (Mutschmann et al., 2000; Bradley et al., 2002; Weldon et al., 2004). Factors such as temperature (Woodhams et al., 2003; Piotrowski et al., 2004) and moisture (Johnson \& Speare, 
2003) have been suggested to be the most important environmental factors influencing growth and survival of B.d. under laboratory conditions and possibly control the prevalence of the pathogen and the timing of chytridiomycosis outbreaks in the field (Berger et al., 2004; McDonald et al., 2005; Woodhams \& Alford, 2005; Kriger \& Hero, 2006).

Recently, researchers have developed some techniques to predict ecologically suitable areas for the establishment of species in regions where they have not being found yet (Peterson \& Vieglais, 2001; Peterson, 2003). This methodology builds an ecological niche model based on the values of environmental variables (niche dimensions) at known localities for the target species. Some global predictive models for the potential distribution of B.d. have been proposed (Ron, 2005; Puschendorf et al., 2009; Rödder et al., 2009). Ron (2005) described specific regions in South America such as the Brazilian Atlantic forest, the temperate forest in Chile and western Argentina (south to $30^{\circ} \mathrm{S}$ ), northeastern Argentina, Uruguay and Paraguay. Later findings of the fungus in native and exotic species of nine countries in and around these regions support the hypothesis (i.e., Ron \& Merino, 2000; Mazzoni et al., 2003; Seimon et al., 2005; Barrionuevo \& Mangione, 2006; Carnaval et al., 2006; Fox et al., 2006; Barrionuevo et al., 2008; Ruiz \& Rueda-Almonacid, 2008; Arellano et al., 2009; Borteiro et al., 2009; Ghirardi et al., 2009; Solis et al., 2009). In Argentina, the earliest evidence of this fungus dates from 2002 (Herrera et al., 2005), and since then new reports have expanded the extent of $B . d$. distribution to a wide range of environments in the country (Arellano et al., 2006, 2009; Barrionuevo \& Mangione, 2006; Fox et al., 2006; Ghirardi et al., 2009).

Any attempt to limit further spread of the pathogen requires extensive knowledge of the current distribution of B.d. (Rödder et al., 2009). Therefore, our study in Argentina was focused on prediction of B.d. distribution through niche modeling based on reports of infected amphibians at different localities and by the use of environmental variables. Understanding the range of environmental factors favouring growth of this fungus will help us to promote conservation tools for more susceptible amphibian species in Argentina, expanding the monitored areas and focusing on species at risk.

For identifying potential areas of distribution of B.d. in Argentina, we elaborated prediction maps using the Genetic Algorithm for Rule-Set Prediction model (Desktop GARP v. 1.1.4) (Scachetti-Pereira, 2001). The GARP uses presence data of the target species and environmental variables, then to run the model we used localities of B.d. presence infecting amphibians in Argentina from published data (Herrera et al., 2005; Barrionuevo \& Mangione, 2006; Fox et al., 2006; Arellano et al., 2006, 2009; Ghirardi et al., 2009) and 15 climatic variables extracted from the World Clim interpolated map database (30 s; $\sim 1 \mathrm{~km}$ resolution) (Hijmans et al., 2005).

We generated 100 models (iterations) and choose the 20 most robust (Peterson, 2001; Ron, 2005). The resulting geographic predictions in the output maps were exported to ESRI ArcView (version 3.2) with the Spatial Analyst extension and were overlapped to obtain one definitive map of potential niche distribution for B.d. The suitable regions for B.d. in Argentina were classified with an Overlap Index (OI) from 0 to 1 . To describe the areas we used the phytogeographical division of Argentina proposed by Cabrera (1976).

In the localities with positive B.d., we used the zonal statistic routine to extract from the digital maps the environmental variables values from each point (ArcView 3.2, Spatial Analyst). These values were also used to run Principal Component Analysis (PCA; implemented in XLSTAT v.3.0) to visualize the degree of clustering in environmental space among Argentinean localities where B.d. was found.

We identified nine localities of known occurrence of B.d. infecting six amphibians' species (Herrera et al., 2005; Barrionuevo \& Mangione, 2006; Fox et al., 2006; Arellano et al., 2006; 2009; Ghirardi et al., 2009).

Final map resulted with areas highly suitable for the presence of B.d. (OI > 0.7) dispersed irregularly over all country (Fig. 1). There are localities with highly suitable for the fungus in central and north regions of Phytogeographic Provinces (P.P.) of Yungas and Prepuneña (northwest of Argentina). Also, there is a highly suitable region in southern of Chaqueña P.P., a big portion of Espinal P.P., almost all Pampeana P.P., and a portion of Paranaense P.P. (northeast and central east Argentina) (Fig. 1). On the west of Argentina, there is also high probability of B.d. occurrence in some zones of Puneña P.P. and Monte P.P. Finally a huge extension of Patagonica P.P., and some isolates patches of Altoandina P.P. (Fig. 1). 
Fig. 1 Predicted distribution for B.d. presence in Argentina. Circles represent localities of known presence of B.d. used to construct the model

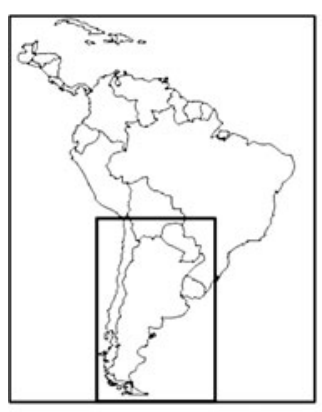

NEOTROPICAL REGION

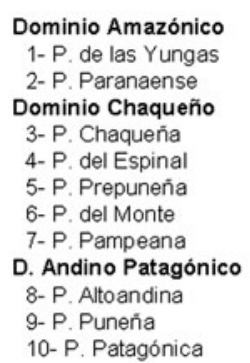

ANTARTIC REGION

Dominio Subantártico 11- P. Subantártica 12- P. Insular

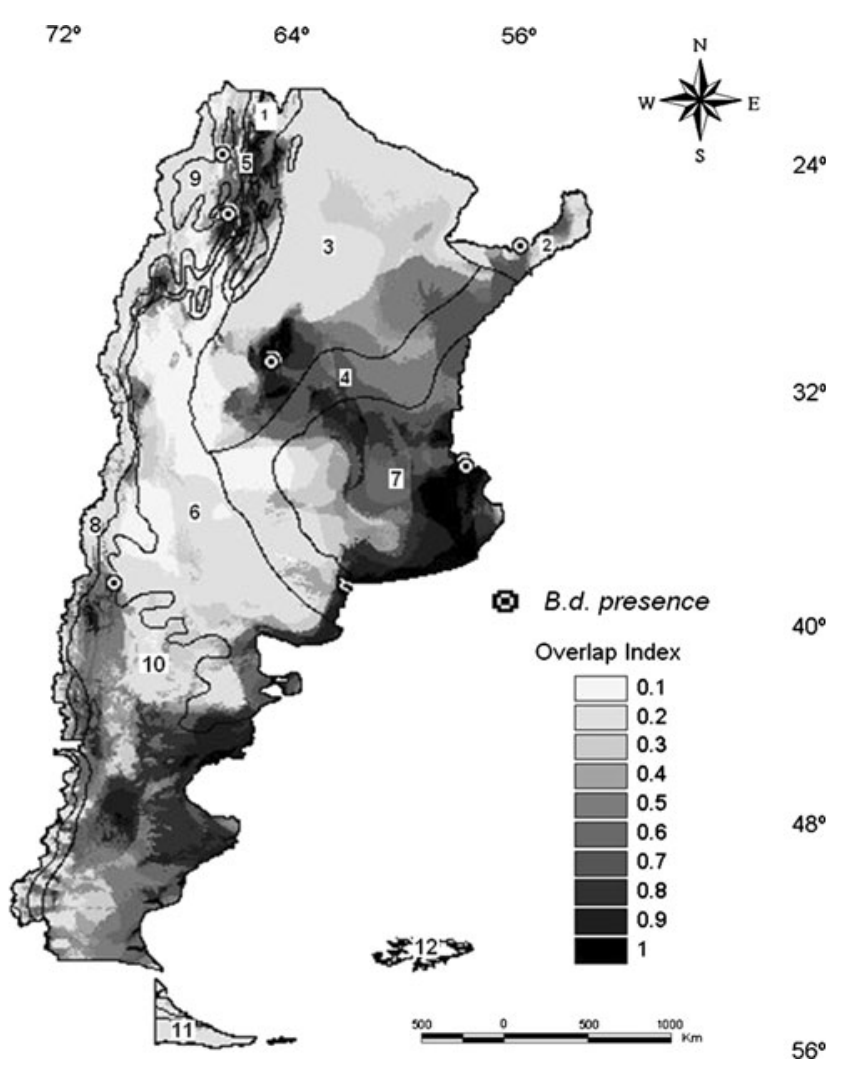

(3) annual precipitation, (4) precipitation of wettest month and (5) precipitation of coldest quarter, explaining $63.6 \%$ of the variance of the system. Principal Component II explained $19.0 \%$ and was highly positively correlated only with seasonal temperature, while Principal Component III explained $9.0 \%$ and was positively correlated with (1) mean diurnal range of temperature and (2) annual temperature range.

The large surface area of Argentina and its variable topography provide a unique and wide array of climates, vegetation patterns and aquatic environments. In this study, regions with highest incidence of B.d. include the habitats with the most diverse amphibian fauna in Argentina [E. bicolor from the Atlantic Forest (Paranaense P. P.), inhabit in one of the five biodiversity hotspots of South America (Myers et al., 2000; Conservation International 2005)] and some of them have endemic and endangered species [T. atacamensis: categorized as in critical danger of extinction, T. pisanoi: endangered and A. patagonicus: endangered (International Union for Conservation of Nature and Natural Resources (IUCN) 2007)]. 
Table 1 Environmental global conditions at all localities of known occurrence of B.d. in Argentina

\begin{tabular}{|c|c|c|c|c|}
\hline Variable & Min & Max & Mean & SD \\
\hline Mean annual temperature & 5.0 & 21.4 & 14.7 & 4.8 \\
\hline Mean diurnal range & 9.4 & 15.2 & 12.5 & 2.3 \\
\hline Isothermally & 0.4 & 0.6 & 0.5 & 0.1 \\
\hline Temperature seasonality & 33.2 & 54.2 & 44.5 & 6.1 \\
\hline Maximum temperature of warmest month & 15.5 & 32.6 & 26.9 & 5.0 \\
\hline Minimum temperature of coldest month & -9.2 & 10.3 & 2.3 & 5.9 \\
\hline Annual temperature range & 22.0 & 28.0 & 24.6 & 2.4 \\
\hline Mean temperature of wettest quarter & 4.0 & 23.2 & 17.9 & 7.0 \\
\hline Mean temperature of driest quarter & 0.3 & 17.1 & 10.1 & 4.5 \\
\hline Annual precipitation & 142.0 & 1799.0 & 808.2 & 508.2 \\
\hline Precipitation of driest month & 25.0 & 174.0 & 98.9 & 43.1 \\
\hline Precipitation of wettest month & 0.0 & 95.0 & 31.6 & 33.8 \\
\hline Precipitation seasonality & 14.0 & 102.0 & 48.8 & 35.2 \\
\hline Precipitation of warmest quarter & 18.0 & 438.0 & 240.8 & 117.1 \\
\hline Precipitation of coldest quarter. & 2.0 & 329.0 & 108.9 & 110.6 \\
\hline
\end{tabular}

Values are estimated with random point generator (ArcView 3.2) from digital maps. Temperatures are in ${ }^{\circ} \mathrm{C}$ and precipitations in mm

The high risk areas emerged from our hypothesis are ecologically similar to those where the fungus has already been found in other parts of the world. However it is important to remember that these extrapolation algorithms only find regions that "resemble", in terms of the layers provided, those where occurrence points are located. Then, the rest of the process is an interpretation of results (Soberon \& Peterson, 2005).

Ron (2005) predicted suitability regions for B.d. in the Brazilian Atlantic Forest, where declines in amphibians populations have been already reported (Heyer et al., 1988), although this declining has not been confirmed as a consequence of chytridiomycosis. In the present study, we report suitable areas for B.d. occurrence in some portions of Paranaense P.P., limited by the Brazilian Atlantic Forest to the east and north. Also, in the Pampas's plain (Pampeana P.P.) there is a high suitability predicted area, limited on the southwest by Uruguay, where there is a record of a captive population of $L$. catesbeianus crashed by chytridiomycosis (Mazzoni et al., 2003).

While there have been no reports of large scale mortality rates in Argentina yet, it seems very urgent to learn more about the dispersion and host range of B.d. to be more confident of finding useful information to generate conservation tools to protect native amphibians from a sudden outbreak of this disease.
Acknowledgments We are grateful to Javier. A. López for his help in the organization and critical reading of this manuscript.

\section{References}

Arellano, M. L., M. Agostini, R. Herrera, M. M. Steciow, E. O. Lavilla \& D. Barraso, 2006. Nuevo hallazgo de quitridiomicosis en el noreste de la provincia de Buenos Aires. Libro de Resúmenes del VII Congreso Argentino de Herpetología 2006, 29 de Noviembre al 1 Diciembre; Corrientes, Argentina: 124 pp.

Arellano, M. L., D. P. Ferraro, M. M. Steciow \& E. O. Lavilla, 2009. Infection by the chytrid fungus Batrachochytrium dendrobatidis in the yellow belly frog (Elachistocleis bicolor) from Argentina. Herpetological Journal 19: $217-$ 220.

Barrionuevo, S. \& S. Mangione, 2006. Chytridiomycosis in two species of Telmatobius (Anura: Leptodactylidae) from Argentina. Diseases of Aquatic Organisms 73: 171-174.

Barrionuevo, J. S., R. Aguayo \& E. O. Lavilla, 2008. First record of chytridiomycosis in Bolivia (Rhinella quechua; Anura: Bufonidae). Diseases of aquatic organisms 82: 161-163.

Berger, L., R. Speare, H. B. Hines, G. Marantelli, A. D. Hyatt, K. R. Mc Donald, L. F. Skerrat, V. Olsen, J. M. Clark, G. Gillespie, M. Mahony, N. Sheppard, C. Williams \& M. J. Tyler, 2004. Effect of season and temperature on mortality in amphibians due to chytridiomycosis. Australian Veterinary Journal 82: 31-36.

Borteiro, C., J. C. Cruz, F. Kolenc \& A. Aramburu, 2009. Chytridiomycosis in frogs from Uruguay. Diseases of Aquatic Organisms 84: 159-162. 
Bradley, G. A., P. C. Rosen, M. J. Svedl, J. R. Jones \& J. E. Longcore, 2002. Chytridiomycosis in native Arizona frogs. Journal of Wildlife Diseases 38: 206-212.

Cabrera, A. L., 1976. Regiones fitogeográficas argentinas. Enciclopedia Argentina de Agricultura y Jardinería. Segunda Edición, Tomo II. Editorial. ACME S.A.C.I, Buenos Aires: $85 \mathrm{pp}$.

Carnaval, A. O. Q. C., R. Puschendorf, O. L. Peixoto, V. K. Verdade \& M. T. Rodrigues, 2006. Amphibian chytrid fungus broadly distributed in the Brazilian Atlantic Rain Forest. EcoHealth 2006: 1-8.

Conservation International, 2005. Biodiversity Hotspots. Accessed 11 August 2009 [available on internet at http:// www.biodiversityhotspots.org/xp/Hotspots].

Fox, S. F., A. L. Greer, R. Torres-Cervantes \& J. P. Collins, 2006. First case of ranavirus associated morbidity and mortality in natural populations of the South American frog Atelognathus patagonicus. Diseases of aquatic organisms 72: 87-92.

Ghirardi, R., J. N. Lescano, M. S. Longo, G. Robledo, M. M. Steciow \& M. G. Perotti, 2009. Batrachochytrium dendrobatidis in Argentina: first record in Leptodatylus gracilis and another record in Leptodactylus ocellatus. Herpetological Review 40: 175-176.

Herrera, R. A., M. M. Steciow \& G. S. Natale, 2005. Chytrid fungus parasitizing the wild amphibian Leptodactylus ocellatus (Anura: Leptodactylidae) in Argentina. Diseases of aquatic organisms 64: 247-252.

Heyer, W. R., A. S. Rand, C. A. Goncalvez Da Cruz \& O. L. Peixoto, 1988. Decimations, extinctions and colonizations of frogs populations in Southeast Brazil and their evolutionary implications. Biotropica 20: 230-235.

Hijmans R. J., S. Cameron \& J. Parra, 2005. WORLDCLIM 1.2. Museum of Vertebrate Zoology, University of California Berkeley [available on internet at http:// biogeo.berkeley.edu/worldclim/methods.htm].

IUCN International Union for Conservation of Nature and Natural Resources (IUCN), 2007. Conservation International and NatureServe. Global Amphibian Assessment [available on internet at www.globalamphibians.org).

Johnson, M. \& R. Speare, 2003. Survival of Batrachochytrium dendrobatidis in water: quarantine and control implications. Emerging Infectious Diseases 9: 922-925.

Kriger, K. M. \& J. M. Hero, 2006. Large scale seasonal variation in the prevalence and severity of chytridiomycosis. Journal of Zoology 271: 352-359.

Longcore, J. E., A. P. Pessier \& D. K. Nichols, 1999. Batrachochytrium dendrobatidis gen et $\mathrm{sp}$. nov. a chytrid pathogenic to amphibians. Mycologia 91: 219-227.

Mazzoni, R., A. A. Cunningham, P. Daszak, A. Apolo, E. Perdomo \& G. Speranza, 2003. Emerging pathogen of amphibians in frogs (Rana catesbeiana) farmed for international trade. Emerging Infectious Diseases 9: 995-998.

McDonald, K. R., D. Mendez, R. Muller, A. B. Freeman \& R. Speare, 2005. Decline in the prevalence of chytridiomycosis in upland frog populations in North Queensland, Australia. Pacific Conservation Biology 11: 114-120.

Mutschmann, F., L. Berger, P. Zwart \& C. Gaedicke, 2000. Chytridiomycosis in amphibians: first report in Europe. Berl Munch Tierarztl Wochenschr 113: 380-383.
Myers, N., R. A. Mittermeier, C. G. Mittermeier, G. A. B. da Fonseca \& J. Kent, 2000. Biodiversity hotspots for conservation priorities. Nature 403: 853-858.

Peterson, A. T., 2001. Predicting species' geographic distributions based on ecological niche modeling. The Condor 103: 599-605.

Peterson, A. T., 2003. Predicting the geography of species' invasions via ecological niche modeling. Quarterly Review of Biology 78: 419-433.

Peterson, A. T. \& D. A. Vieglais, 2001. Predicting species invasions using ecological niche modeling: new approaches from bioinformatics attack a pressing problem. BioScience 51: 363-371.

Piotrowski, J. S., S. L. Annis \& J. E. Longcore, 2004. Physiology of Batrachochytrium dendrobatidis, a chytrid pathogen of amphibians. Mycologia 96: 9-15.

Puschendorf, R., A. C. Carnaval, J. VanDerWal, H. ZumbadoUlate, G. Chaves, F. Bolaños \& R. A. Alford, 2009. Distribution models for the amphibian chytrid Batrachochytrium dendrobatidis in Costa Rica: proposing climatic refuges as a conservation tool. Diversity and Distributions 15: 401-408.

Rödder, D., J. Kielgast, J. Bielby, S. Schmidtlein, J. Bosch, T. W. Garner, M. Veith, S. F. Walker, M. C. Fisher \& S. Lötters, 2009. Global amphibian extinction risk assessment for the panzootic chytrid fungus. Diversity 1: 52-65.

Ron, S. R., 2005. Predicting the distribution of the amphibian pathogen Batrachochytrium dendrobatidis in the New World. Biotropica 37: 209-221.

Ron, S. R. \& A. Merino, 2000. Declinación de anfibios del Ecuador: Información general y primer reporte de chytridiomycosis para Sudamérica. Froglog 42: 2-3.

Ruiz, A. \& V. J. Rueda-Almonacid, 2008. Batrachochytrium dendrobatidis and chytridiomycosis in anuran amphibians of Colombia. EcoHealth 5: 27-33.

Scachetti-Pereira, R., 2001. Desktop GARP v. 1.1.4. The University of Kansas Biodiversity Research Center, Lawrence.

Seimon, T. A., G. Hoernig, P. Sowell, S. Halloy \& A. Seimon, 2005. Identification of chytridiomycosis in Telmatobius marmoratus at $4,450 \mathrm{~m}$ in the Cordillera Vilcanota of southern Peru. In Lavilla, E. O. \& I. de la Riva (eds), Studies on the Andean frogs of the Genera Telmatobius and Batrachophrynus, pp. 275-283. Monografias de Herpetología 7. Asociación Herpetológica Española, Valencia.

Soberon, J. \& A. T. Peterson, 2005. Interpretation of models of fundamental ecological niches and species' distributional areas. Biodiversity Informatics 2: 1-10.

Solis, R., G. Lobos, S. F. Walker, M. C. Fisher \& J. Bosch, 2009. Presence of Batrachochytrium dendrobatidis in feral populations of Xenopus laevis in Chile. Biological Invasions. doi:10.1007/s10530-009-9577-2.

Weldon, C., L. H. du Preez, A. D. Hyatt, R. Muller \& R. Speare, 2004. Origin of amphibian chytrid fungus. Emerging Infectious Diseases 10: 2100-2105.

Woodhams, C. D. \& R. A. Alford, 2005. Ecology of chytridiomycosis in rainforest stream frog assemblages of Tropical Queensland. Conservation Biology 19: 1449-1459.

Woodhams, D. C., R. A. Alford \& G. Marantelli, 2003. Emerging disease of amphibians cured by elevated body temperature. Diseases of Aquatic Organisms 55: 65-67. 